\title{
Pemanfaatan Solar Sel dan Budidaya Perikanan Sebagai Upaya Menuju Kemandirian Finansial di Sekolah KAMI
}

\section{Utilization of Solar Cells and Fisheries Culture as Efforts Towards Financial Independence in Sekolah KAMI}

\author{
${ }^{1}$ Murie Dwiyaniti, ${ }^{2}$ Riandini, ${ }^{3}$ Eddy Supriyono \\ ${ }^{1}$ Program Studi Teknik Otomasi Listrik Industri, Jurusan Teknik Elektro, \\ Politeknik Negeri Jakarta \\ 2 Program Studi Instrumentasi dan Kontrol Industri, Jurusan Teknik Elektro, \\ Politeknik Negeri Jakarta \\ ${ }^{3}$ Departemen Budidaya Perairan, Fakultas Perikanan dan Ilmu Kelautan, \\ Institut Pertanian Bogor
}

Korespondensi: M. Dwiyaniti, murie.dwiyaniti@elektro.pnj.ac.id

\begin{abstract}
Sekolah Kami is a non-profit school that provides free non-formal education to scavengers and poor children. This school is located in the middle of scavenger shanties and landfills located in Pemulung Village, Bintara Jaya Village, West Bekasi District, Bekasi City. As an informal school that is managed independently, it requires substantial funding for operations. So far, funding has only relied on donors and the personal money of the School owner. So that the purpose of community service, strive for schools to obtain sustainable income for school operations by utilizing solar cells and aquaculture. The method consists of two stages, namely, build physical capital in the form of fish ponds and solar cell electricity sources; train and assist teachers in Sekolah Kami so that they can manage the facilities and infrastructure built. The results of this activity are the construction of fish ponds with $3 \times 1 \times 0.8$ meters of cast cement with two ponds for catfish and tilapia, the realization of DC power sources from renewable energy, namely solar cells with $300 \mathrm{WP}$ power for garden lighting, two pond pumps and an aquaponics pump, and aquaponics are built to grow mustard and watercress, and trained teachers can manage everything well. Good yields and sold in the market indicate this. Money from the sale has been used for school operations and buying fish seeds.
\end{abstract}

Keywords: Catfish cultivation, tilapia, financially independent, solar cells, Sekolah Kami.

\begin{abstract}
Abstrak. Sekolah Kami merupakan sekolah nonprofit yang menyediakan pendidikan gratis non formal kepada anak-anak pemulung dan dhuafa. Sekolah ini terletak di tengah lapak pemulung dan tempat pembuangan sampah yang berlokasi di Kampung Pemulung Kelurahan Bintara Jaya, Kecamatan Bekasi Barat, Kota Bekasi. Sebagai sekolah informal yang dikelola secara swadaya sangat memerlukan dana yang cukup besar untuk operasional. Selama ini pembiayaan hanya mengandalkan donatur dan uang pribadi pemilik Sekolah. Pengabdian masyarakat ini bertujuan mengupayakan agar sekolah mendapatkan pemasukan secara berkelanjutan untuk operasional sekolah dengan memanfaatkan solar sel dan perikanan budidaya. Metode yang dilakukan terdiri dari dua tahap, yaitu membangun modal fisik berupa kolam ikan dan sumber listrik solar sel; melatih dan melakukan pendampingan untuk guru di Sekolah Kami agar dapat mengelola sarana dan prasarana yang dibangun. Hasil kegiatan ini
\end{abstract}


adalah terbangunnya kolam ikan dengan bahan semen cor berukuran $3 \times 1 \times 0,8$ meter sebanyak dua kolam untuk ikan lele dan nila, terwujudnya sumber listrik DC dari energy terbarukan, yaitu solar sel dengan daya $300 \mathrm{WP}$ untuk penerangan taman, dua buah pompa kolam dan satu buah pompa aquaponik, dan terbangunnya aquaponik untuk menanam pokcay dan selada air, serta guru-guru yang telah dilatih dapat mengelola semuanya dengan baik. Hal ini ditandai dengan hasil panen yang cukup baik dan laku dipasaran. Uang hasil penjualan telah digunakan untuk operasional sekolah dan membeli bibit ikan dan pakan.

Kata Kunci: Budidaya lele, nila, solar sel, Sekolah Kami.

\section{Pendahuluan}

Kemiskinan merupakan salah satu pemicu munculnya pemulung dan dhuafa. Menurut Laporan Bulanan Data Sosial Ekonomi, Badan pusat Statistik, Edisi 99 tahun 2018, jumlah penduduk miskin pada Maret 2018 sebanyak 25,95 juta orang (9,82 persen) (BPS, 2018). Penduduk miskin tersebut diantaranya terletak di daerah Bekasi, Bintara Jaya. Sebanyak 700 KK tinggal di daerah tersebut yang berprofesi sebagai pemulung dan tidak memiliki kartu identitas (Chotim, 2017). Kondisi keluarga yang migran dan miskin mendorong pelibatan seluruh anggota keluarga untuk ikut bekerja sebagai pemulung (Nuraeni \& Santana, 2015), sehingga tak jarang pemulung anak berkeliaran di waktu-waktu yang seharusnya anak tersebut belajar di sekolah. Selain itu, karena orang tua mereka tidak mempunyai kartu identitas. Pemulung anak umumnya juga tidak memiliki akta kelahiran sehingga sulit memperoleh pelayanan publik seperti kesehatan dan pendidikan. Beranjak dari kondisi inilah berdiri Sekolah informal yang dikelola secara swadaya untuk menampung kegiatan belajar anak-anak pemulung dan dhuafa. Sekolah informal tersebut diberi nama Sekolah Kami (Syarifah, 2013).

Sekolah Kami merupakan sekolah non profit yang bertujuan menyediakan pendidikan gratis non formal kepada anak-anak pemulung dan dhuafa. Sekolah ini terletak di tengah lapak-lapak pemulung dan tempat pembuangan sampah yang berlokasi di Kampung Pemulung Kelurahan Bintara Jaya, Kecamatan Bekasi Barat, Kota Bekasi. Status lahan sekolah adalah sewa. Jumlah siswa pada Sekolah Kami adalah 125 orang dengan rentang usia 6-16 tahun, jenjang SD sampai SMP. Sedangkan jumlah guru sebanyak 8 orang. Sekolah dimulai pada pukul 07.0013.00 WIB. Pada jam 11.00 WIB siswa diberikan makanan nasi dan lauk pauk.

Materi pendidikan dan pengajaran dibatasi pada pelajaran Berhitung, Bahasa Indonesia, Ilmu Pengetahuan Umum, Budi Pekerti, Agama Islam, dan keterampilan. Materi keterampilan yang diberikan antara lain kreativitas membuat aneka sabun, rajutan, sulaman, kue, mendaur ulang sampah, dan membatik.

Hasil kegiatan keterampilan jika bagus akan dijual dan pembuatnya diberikan reward sebesar $2 \%$ dari keutungannya. Ini merupakan salah satu upaya untuk membentuk paradigma kemandirian bagi siswa dan sekolah, namun nilai jualnya tidak besar dan tidak dapat dijadikan income generating bagi sekolah secara berkelanjutan. Padahal sekolah memerlukan dana yang cukup besar untuk operasional. Biaya operasional yang paling besar adalah biaya sewa lahan, listrik, dan makan. Selama ini, pembiayaan hanya mengandalkan donatur dan uang pribadi pemilik Sekolah. Jika donatur berhenti, kemungkinan sekolah akan tutup karena tidak punya uang untuk biaya operasional. Oleh karena itu sangatlah penting upaya untuk menekan biaya operasional dan menjadikan sekolah berdaya untuk keberlangsungan hidupnya.

Salah satu upaya yang dilakukan adalah membuatkan usaha perikanan budidaya lele, nila dan akuaponik (Darseno, 2013). Hasilnya akan dijual secara langsung ke konsumen pertama yaitu tukang sayur dan warung makan sehingga mendapatkan keuntungan lebih baik (Triyanti \& Shafitri, 2017). Agar tidak memberatkan biaya listrik sekolah, pengelolaan sirkulasi airnya menggunakan sumber listrik DC yang berasal dari energi baru dan terbarukan khususnya solar 
sel (Abrori, dkk., 2017). Kegiatan ini diharapkan dapat bermanfaat untuk membantu finansial sekolah. Disamping itu ikan lele, nila, pokcay, dan selada air dapat dimanfaatkan sebagai lauk pauk yang bergizi tinggi untuk meningkatkan gizi anak pemulung dan dhuafa.

\section{Metode Pelaksanaan}

Tempat dan Waktu. Kegiatan Program Kemitraan Masyarakat dilaksanakan di Sekolah Kami yang berlokasi di Kampung Pemulung Kelurahan Bintara Jaya, Kecamatan Bekasi Barat, Kota Bekasi. Waktu pelaksanaan bertahap dimulai pada bulan Juni sampai dengan Oktober 2019.

Khalayak Sasaran. Sasaran pengabdian ini adalah guru dan teknisi Sekolah Kami yang berjumlah 8 orang. Guru dan teknisi terlibat langsung dalam setiap kegiatan mulai dari pembangunan sampai pelatihan.

Metode. Metode pengabdian masyarakat ini adalah membangunan usaha perikanan budidaya dan aquaponik yang pengelolaan sirkulasi airnya menggunakan sumber listrik solar sel dengan tahapan sebagai berikut:

1. Tahap pembangunan sistem kelistrikan DC dari energi baru dan terbarukan untuk sumber listrik penerangan dan pompa yang meliputi:

a Merancang tata letak dan kebutuhan daya listrik solar sel

b Membuat rangka dan panel outdoor untuk sistem solar sel

c Menghubungkan atau menginstalasi beban-beban listrik ke panel solar sel

d Membangun sistem sirkulasi air dengan pompa untuk kolam ikan lele dan nila serta akuaponik

2. Tahap pembuatan kolam ikan untuk budidaya ikan lele dan nila dalam rangka menjadikan income generating sekolah, yaitu:

a Membuat kolam dengan ukuran 3x1 meter dengan kedalaman 0,8 meter sebanyak dua kolam, terbuat dari cor semen

b Melakukan tes kualitas air pada kolam meliputi $\mathrm{pH}$, oksigen terlarut (DO), suhu, dan salinitas

c Melakukan pengkondisian air kolam dengan prebiotik, kapur, dan lain-lain

d Melakukan tebar ikan lele dan nila

3. Tahap pembuatan aquaponik untuk menanam pokcay dan salada air.

4. Tahap transfer knowledge dan pendampingan untuk menjadikan SDM Sekolah Kami mandiri dalam pengelolaan sistem yang telah dibangun, meliputi:

a Melakukan pelatihan perawatan dan perbaikan terhadap system kelistrikan solar sel;

b Melakukan pelatihan pengelolaan budidaya ikan lele, nila, dan aquaponik.

Indikator keberhasilan. Indikator keberhasilan dari kegiatan ini adalah:

1. Terselesaikannya semua pembangunan kolam, aquaponik, dan panel solar sel sebagai sumber listrik yang digunakan untuk menyalakan pompa sirkulasi air.

2. Terlaksananya kegiatan transfer knowledge ke guru dalam perawatan dan perbaikan terhadap system kelistrikan DC dan pengelolaan budidaya ikan lele, nila, dan aquaponik.

Metode Evaluasi. Kegiatan pengabdian masyarakat dievaluasi secara bertahap untuk mengukur ketercapaian indikator keberhasilan dengan cara melakukan pengecekan kesesuaian pekerjaan yang telah diselesaikan dengan jadwal yang telah dibuat. Jadwal pekerjaan dibuat secara terperinci sehingga setiap kegiatan diharapkan dapat terpantau dan terselesaikan tepat waktu.

\section{Hasil dan Pembahasan}

Upaya menuju kemandirian finansial, kegiatan pengabdian masyarakat di Sekolah Kami adalah memberikan modal fisik, pengetahuan dan keterampilan 
kepada Guru-guru. Modal fisik dalam bentuk pembangunan kolam ikan, sistem kelistrikan DC dan aquaponik. Sedangkan pengetahuan dan keterampilan berupa kegiatan transfer knowledge terkait dengan perawatan dan budidaya ikan.

\section{A. Pembangunan Sistem Kelistrikan DC}

Sistem kelistrikan DC dibangun dengan memanfaatkan tenaga surya yang sangat berlimpah. Tujuan penggunaan sistem DC tenaga surya ini adalah agar tidak membebani biaya listrik sekolah. Beban listrik yang akan digunakan adalah lampu taman dan tiga buah pompa. Perhitungan beban dan kebutuhan solar sel, sebagai berikut:

1. Perhitungan beban listrik:

- Lampu 3 bh x 4,5 watt x 6 jam (menyala) = 81 watt

- Pompa celup 3 bh x 60 watt x 6 jam (menyala) $=1080$ watt

- Jumlah total daya (lampu + pompa celup) adalah $1161 \mathrm{watt} / \mathrm{hari}$

- Jumlah solah panel = total daily watt : charging efektif

$$
=1161 \text { watt : } 5 \text { Jam }=232,2 \text { wattpeak (WP) }
$$

- Jadi solar sel yang digunakan adalah 300 WP sebanyak 1 pcs.

2. Perhitungan jumlah baterai yang diperlukan:

- Baterai yang digunakan adalah $12 \mathrm{~V}, 150 \mathrm{Ah}$, dengan cadangan selama 3 hari.

- Jumlah baterai $=(1161$ watt $/$ day $\times 3$ hari $):(12 \mathrm{~V} \times 150 \mathrm{Ah})=1,936 \mathrm{pcs}$ dibulatkan 2 pcs.

- Jadi baterai yang digunakan sebanyak 2 pcs, baterai $12 \mathrm{~V}, 150 \mathrm{Ah}$

Proses pemasangan solar sel dilaksanakan secara bertahap, dimulai dari pembuatan pondasi untuk rangka atau dudukan solar sel. Pondasi dibuat sedemikian rupa dengan mempertimbangkan kondisi tanah dan berat peralatan. Lingkungan Sekolah Kami merupakan tempat pembuangan sampah sehingga tanahnya sangat labil dan mudah amblas. Beban peralatan yang harus ditopang untuk solar sel, baterai, dan panel sekitar $\pm 100 \mathrm{~kg}$. Kegiatan pemasangan solar sel terlihat pada Gambar 1.
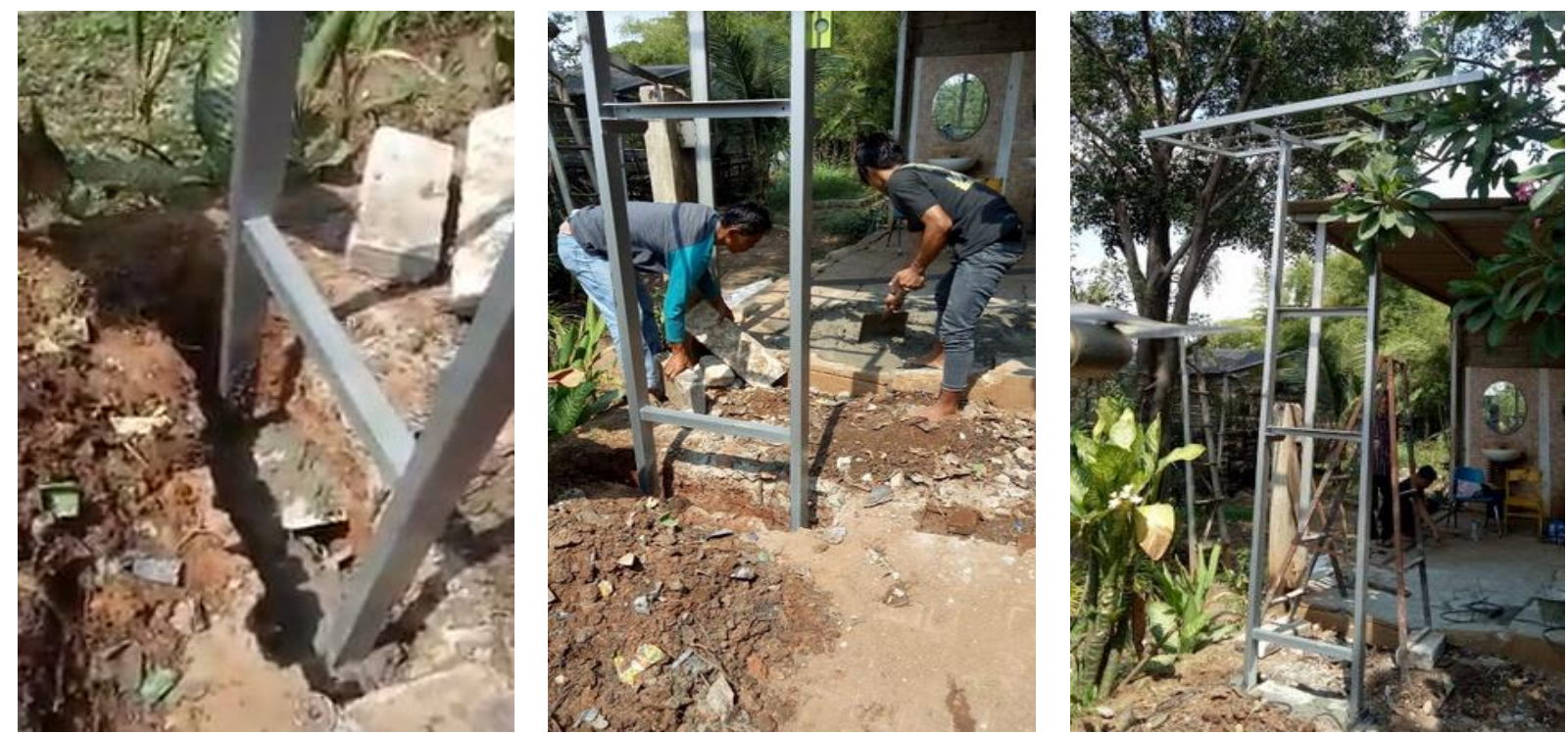

Gambar 1 Kegiatan pemasangan rangka atau dudukan solar sel

Setelah penanaman rangka solar sel kering, kegiatan dilanjutkan dengan peletakkan solar sel, panel, MPPT (charge controller), dan baterai seperti pada Gambar 2. 

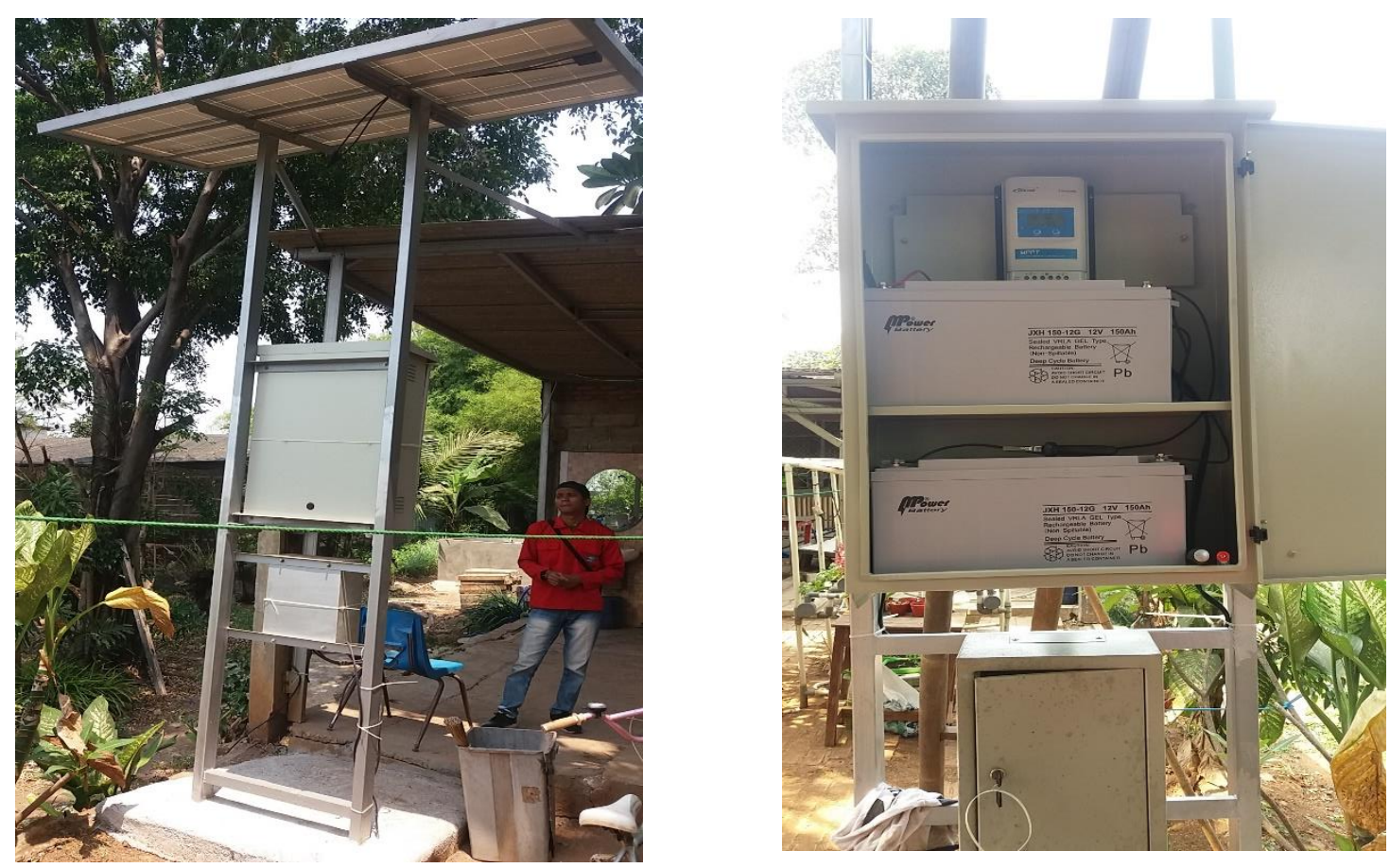

Gambar 2 Peletakan solar sel, panel, MPPT, dan baterai

Instalasi lampu penerangan taman dan pompa dipasang sesuai dengan gambar instalasi. Setelah proses pembangunan sistem kelistrikan DC selesai, dilakukan pengujian dengan hasil seperti pada Tabel 1 .

Tabel 1. Hasil pengukuran sistem kelistrikan DC

\begin{tabular}{lccc}
\hline \multicolumn{1}{c}{ Beban } & Tegangan $(\mathrm{V})$ & Arus $(\mathrm{A})$ & Suhu $(0 \mathrm{C})$ \\
\hline Tanpa beban & 27 & 0 & 25 \\
Lampu & 25,3 & 0,7 & 25 \\
Pompa & 25,3 & 7,6 & 25 \\
Lampu + pompa & 25,3 & 8,3 & 25 \\
\hline
\end{tabular}

Hasil pada Tabel 1 menunjukan bahwa sistem kelistrikan DC telah berhasil dibangun dan bekerja dengan baik. Hal ini ditandai dengan terukurnya tegangan dan arus beban.

\section{B. Pembangunan Kolam Ikan}

Kondisi tanah yang labil dan banyaknya tikus di lingkungan sekitar, serta mempertimbangkan minimalnya biaya pemeliharaan kolam, maka kolam dibuat secara permanen dan kokoh. Kolam ikan dibangun berbahan semen cor dengan ukuran $3 \times 1 \times 0,8$ meter sebanyak 2 kolam. Kolam 1 untuk ikan nila dan kolam 2 untuk ikan lele. Proses pembuatan kolam terdiri dari pengecoran lantai kolam, pembuatan dinding kolam, pelapisan dinding kolam dengan kawat, dan terakhir menghaluskan semua permukaan kolam seperti pada Gambar 3.

Pengkondisian air kolam dimulai setelah semua permukaan kolam kering. Kolam dibiarkan terisi air selama dua minggu untuk menghilangkan bau semen. Air merupakan komponen yang sangat penting untuk hidup ikan sehingga perlu pengelolaan kualitas air. Parameter dasar kualitas air yang sangat diperlukan adalah $\mathrm{pH}$, suhu, oksigen terlarut (DO), kecerahan, dan amoniak.

Perlakuan khusus untuk air dilakukan selama satu minggu dengan menambahkan probiotik dan kapur. Probiotik berguna untuk mempercepat pertumbuhan ikan lele (Rachmawati, dkk., 2015). Penambahan kapur dilakukan untuk mencapai nilai $\mathrm{pH}$ air yang diinginkan. Sedangkan untuk mencapai kondisi 

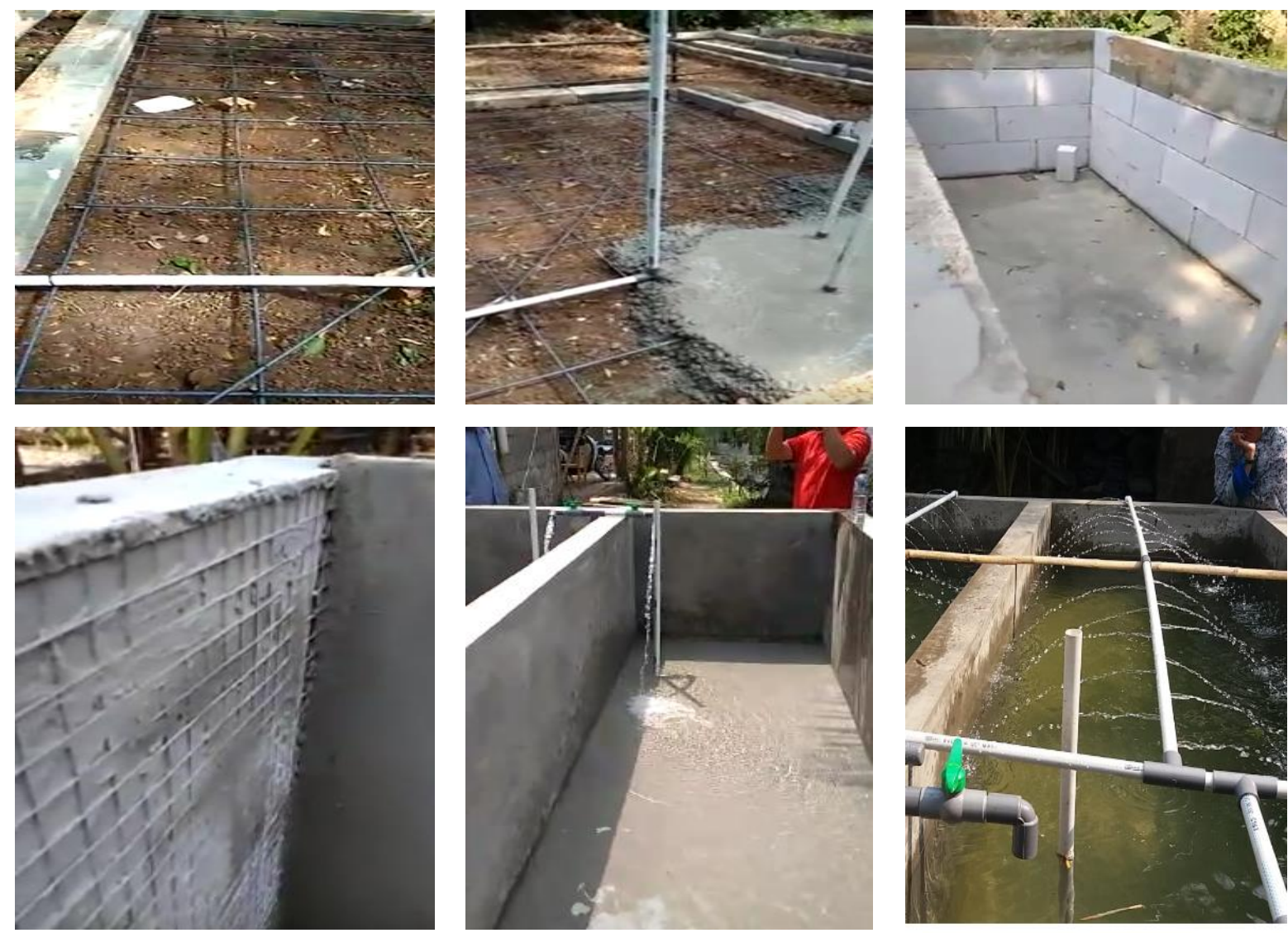

Gambar 3 Proses pembuatan kolam

DO yang sesuai, menggunakan sistem aerasi. Parameter air untuk hidup ikan lele dan nila terlihat di Tabel 2.

Tabel 2 Parameter kualitas air

\begin{tabular}{lccccc}
\hline \multicolumn{1}{c}{ Uraian } & $\begin{array}{c}\text { Suhu } \\
\text { oC }\end{array}$ & $\mathrm{pH}$ & $\begin{array}{c}\mathrm{DO} \\
\mathrm{mg} / \mathrm{L}\end{array}$ & $\begin{array}{c}\text { Kecerahan } \\
\mathrm{cm}\end{array}$ & $\begin{array}{c}\text { Amoniak } \\
\mathrm{mg} / \mathrm{L}\end{array}$ \\
\hline $\begin{array}{l}\text { Standar parameter air } \\
\text { sesuai SNI 6484.3:2014 }\end{array}$ & $25-30$ & $6,5-8$ & $\mathrm{Min} 3$ & $25-30$ & Maks 0,1 \\
$\begin{array}{l}\text { (Nasional, 2014) } \\
\text { Sebelum dilakukan }\end{array}$ & 26 & 6 & 0 & 24 & 0 \\
$\begin{array}{l}\text { treatment } \\
\text { Sesudah dilakukan } \\
\text { treatment }\end{array}$ & 26 & 7,5 & 5 & 27 & 0 \\
\hline
\end{tabular}

Setelah kondisi air mencapai nilai yang diinginkan sesuai SNI 6484.3:2014, dilakukan tebar ikan lele dan nila, seperti pada Gambar 4. Dengan pemberian pakan yang berkualitas dan teratur, pada kolam yang telah dibuat ini, ikan lele dan nila tumbuh besar sesuai dengan umurnya. Hal ini merupakan keberhasilan dari kegiatan ini.

\section{Pembangunan Akuaponik}

Ikan lele menghasilkan kotoran berupa bahan organik yang dapat membahayakan hidup ikan apabila tidak dibersihkan. Padahal kotoran ikan ini sangat baik bagi tanaman karena banyak mengandung nutrisi. Untuk memanfaatkan hal ini sehingga terjadi proses saling menguntungkan antara tanaman dan ikan lele dibuatlah akuaponik (Heriansah, dkk., 2019). 

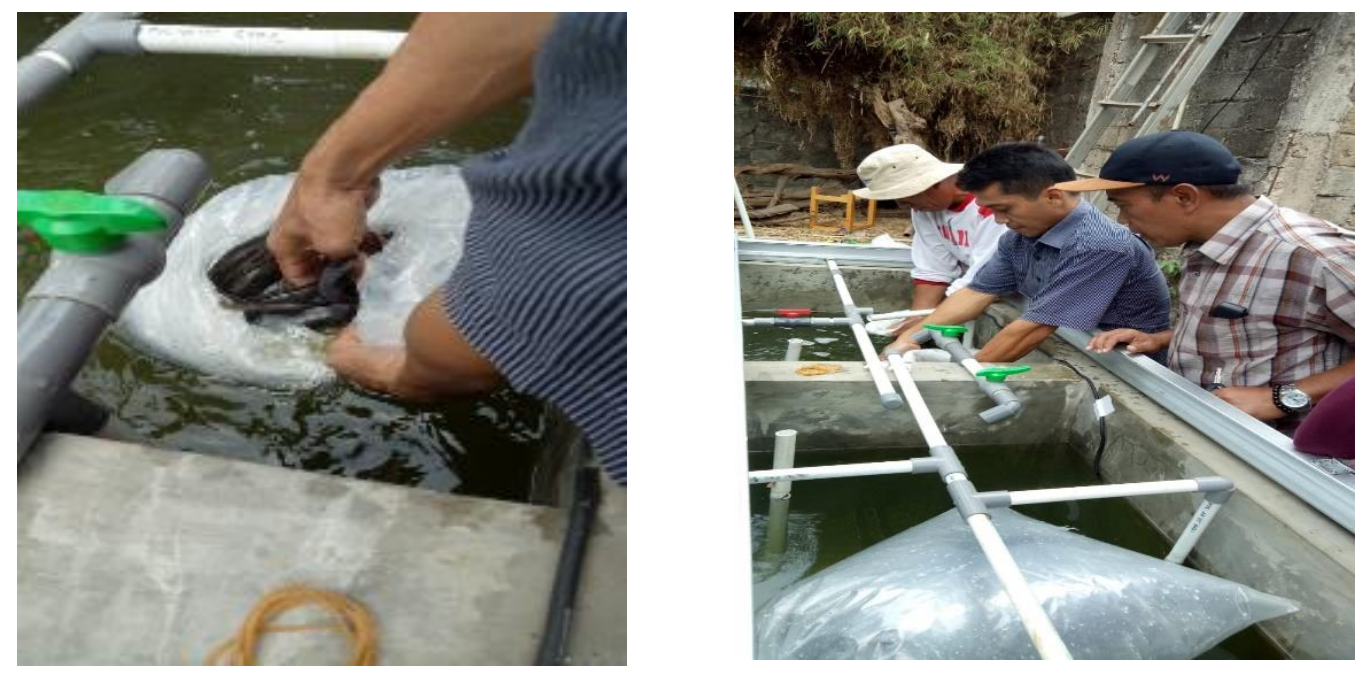

Gambar 4. Tebar ikan lele dan nila pada kolam

Dengan pemberian pakan yang berkualitas dan teratur pada kolam yang telah dibuat ini, ikan lele dan nila tumbuh besar sesuai dengan umurnya. Hal ini merupakan keberhasilan dari kegiatan ini.

\section{Pembangunan Akuaponik}

Ikan lele menghasilkan kotoran berupa bahan organik yang dapat membahayakan hidup ikan apabila tidak dibersihkan. Padahal kotoran ikan ini sangat baik bagi tanaman karena banyak mengandung nutrisi. Untuk memanfaatkan hal ini sehingga terjadi proses saling menguntungkan antara tanaman dan ikan lele dibuatlah akuaponik (Heriansah, dkk., 2019).

Akuaponik adalah sistem budidaya tanaman yang memanfaatkan aliran air kolam ikan sebagai penyalur nutrisi (Rakocy, dkk., 2016). Tanaman berupa pokcay dan selada air ditanam pada netpot. Pada netpot terdapat bagian penampung air yang memiliki tinggi $\pm 4-6 \mathrm{~cm}$. Fungsinya sebagai cadangan air, jadi tanaman tidak akan kekurangan atau telat air. Air kolam melalui sebuah mekanisme diserap tanaman sehingga air menjadi bersih kembali, kemudian air tersebut dibuang kembali ke kolam ikan melalui saluran pembuangan. Hasil akuaponik dapat dilihat pada Gambar 5.

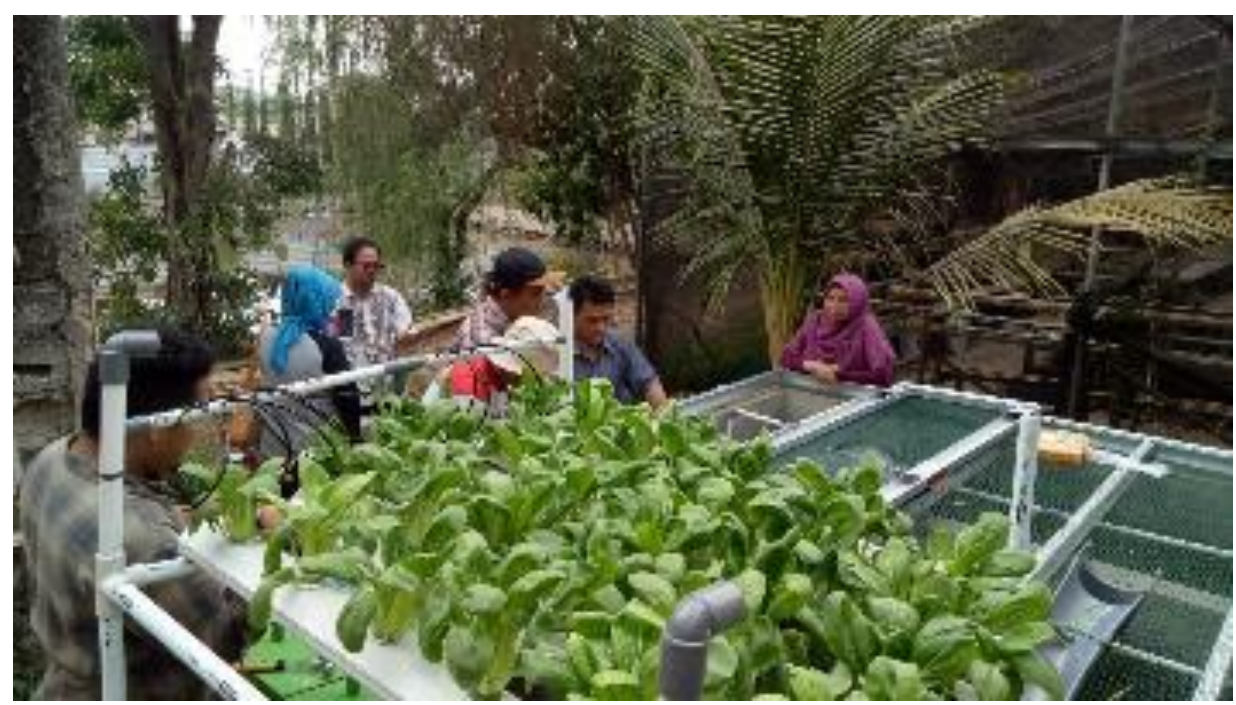

Gambar 5 Aquaponik diatas kolam 


\section{Kegiatan Transfer Knowledge}

Transfer knwolegde tentang pengoperasian dan perawatan solar sel serta pengelolaan kolam ikan dan akuaponik dilaksanakan melalui pelatihan kepada guru-guru di Sekolah Kami seperti pada Gambar 6. Hasil dari pelatihan langsung diterapkan ke media yang telah dibangun.
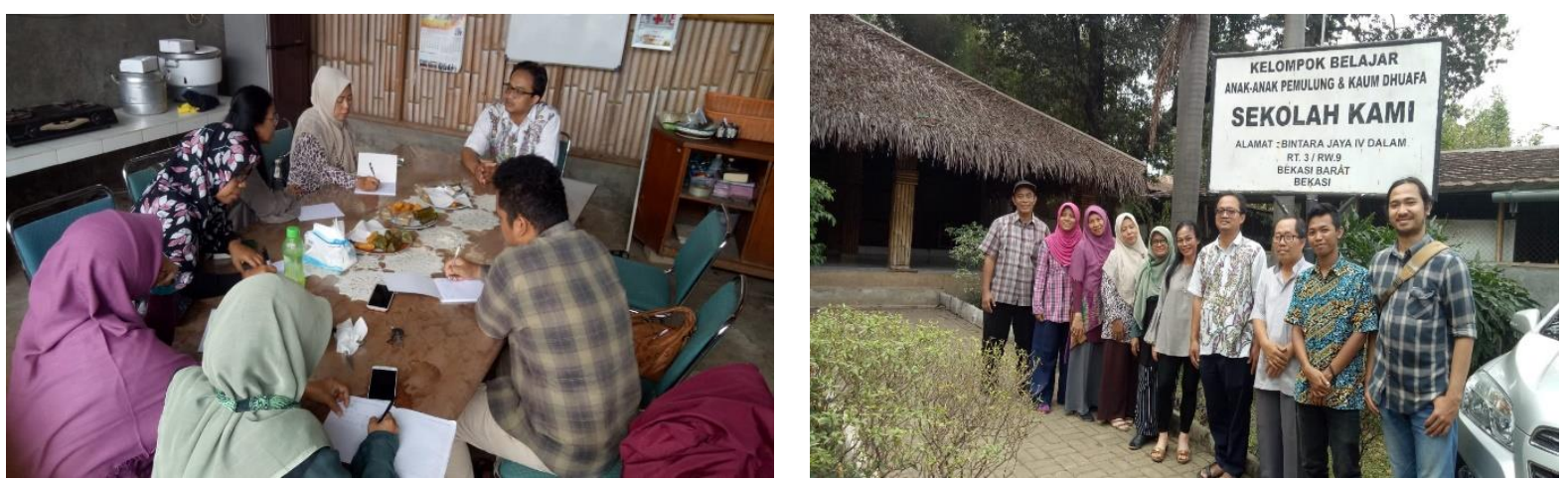

Gambar 6 Pelatihan untuk guru Sekolah Kami

\section{E. Keberhasilan Kegaiatan}

Keberhasilan kegiatan ini terlihat dari setiap tahapan pekerjaan yang telah selesai. Semua sistem kelistrikan telah beroperasi dengan baik. Sumber DC dari solar sel telah berfungsi sebagai sumber listrik untuk penerangan lampu taman dan pompa sirkulasi air pada pengelolaan air kolam dan aquaponik. Keberhasilan juga terlihat dari kondisi tanaman aquaponik yang tumbuh subur dan ikan yang bertambah besar. Selain itu, dari sisi SDM, wawasan dan keterampilan guru meningkat yang ditandai dengan keberlanjutan dalam pengelolaan semua aset yang telah diberikan pada kegiatan pengabdian masyarakat ini.

\section{Kesimpulan}

Kemandirian finansial Sekolah Kami telah dilakukan dengan membangun sistem kelistrikan DC yang bersumber dari tenaga surya, membangun kolam ikan lele dan nila, membangun aquaponik untuk budidaya tanaman, dan pelatihan untuk guru. Integrasi semua kegiatan ini telah berjalan dengan baik dan terbukti keberhasilannya pada kondisi sistem kelistrikan DC yang berfungsi dengan baik, tanaman pada aquaponik tumbuh subur, ikan yang tumbuh besar dan hasil panen yang sesuai perhitungan.

\section{Ucapan Terima Kasih}

Penulis mengucapkan terima kasih kepada Kemenristekdikti yang telah mendanai kegiatan ini melalui skema Program Kemitraan Masyarakat, P3M Politeknik Negeri Jakarta, rekan dosen dari PNJ dan IPB, PLP, mahasiswa, dan mitra Sekolah Kami.

\section{Referensi}

Abrori, M., Sugiyanto, S., \& Niyartama, T.F. (2017). Pemanfaatan Solar Cell Sebagai Sumber Energi Alternatif dan Media Pembelajaran Praktikum Siswa Di Pondok Pesantren "Nurul Iman" Sorogenen Timbulharjo, Sewon, Bantul, Yogyakarta Menuju Pondok Mandiri Energi. Jurnal Bakti Saintek: Jurnal Pengabdian Masyarakat Bidang Sains dan Teknologi, 1(1), 17-26.

BPS. (2018). Laporan Bulanan Data Sosial Ekonomi. Retrieved from https://www.bps.go.id/website/pdf_publikasi/Laporan-Bulanan-Data-SosialEkonomi. 
Chotim. (2017). Ratusan Pemulung di Bekasi Barat Tidak Memiliki KTP. POSKOTA. Retrieved from https://poskota.id/2017/11/28/ratusan-pemulung-di-bekasibarat-tidak-memiliki-ktp/

Darseno, S. (2013). Budi Daya Lele: Agromedia.

Heriansah, H., Nursyahran, N., \& Fathuddin, F. (2019). KKN-PPM Lanrisang Melalui Optimalisasi Usaha Mina-Tani Guna Menunjang Pengembangan KPPN Kabupaten Pinrang, Provinsi Sulawesi Selatan. Jurnal Panrita Abdi, 3(2), 152160.

Nasional, B. S. (2014). Ikan lele dumbo (Clarias sp.) Bagian 3: Produksi induk.

Nuraeni, L., \& Santana, F.D.T. (2015). Persepsi, Pola Pengasuhan, Dan Peran Serta Keluarga Pemulung Tentang Pendidikan Anak Usia Dini (Studi Deskriptif Pada Keluarga Pemulung Dikampung Cibatu Desa Cilame Kecamatan Ngamprah Kabupaten Bandung Barat). Jurnal Ilmiah P2M STKIP Siliwangi, 2(2), 160-168.

Rachmawati, D., Samidjan, I., \& Setyono, H. (2015). 3. Manajemen Kualitas Air Media Budidaya Ikan Lele Sangkuriang (Clarias gariepinus) dengan Teknik Probiotik pada Kolam Terpal di Desa Vokasi Reksosari, Kecamatan Suruh, Kabupaten Semarang. Pena Akuatika: Jurnal Ilmiah Perikanan dan Kelautan, 12(1).

Rakocy, J., Masser, M.P., \& Losordo, T. (2016). Recirculating aquaculture tank production systems: aquaponics-integrating fish and plant culture.

Syarifah, F. (2013). Dr Irina Amongpradja Dirikan Sekolah untuk Anak Pemulung. Retrieved from https://www.liputan6.com/health/read/645648/dr-irinaamongpradja-dirikan-sekolah-untuk-anak-pemulung

Triyanti, R., \& Shafitri, N. (2017). Kajian pemasaran ikan lele (Clarias Sp) dalam mendukung industri perikanan budidaya (studi kasus di Kabupaten Boyolali, Jawa Tengah). Jurnal Sosial Ekonomi Kelautan dan Perikanan, 7(2), 177-191.

Penulis:

Murie Dwiyaniti, Program Studi Teknik Otomasi Listrik Industri, Jurusan Teknik Elektro, Politeknik Negeri Jakarta. E-mail: murie.dwiyaniti@elektro.pnj.ac.id

Riandini, Program Studi Instrumentasi dan Kontrol Industri, Jurusan Teknik Elektro, Politeknik Negeri Jakarta. E-mail: riandini@elektro.pnj.ac.id

Eddy Supriyono, Departemen Budidaya Perairan, Fakultas Perikanan dan Ilmu Kelautan, Institut Pertanian Bogor. E-mail: eddy_supriyono@yahoo.com

Bagaimana men-sitasi artikel ini:

Murie, D., Riandini, \& Eddy, S. (2020). Pemanfaatan Solar Sel dan Budidaya Perikanan sebagai Upaya menuju Kemandirian Financial Sekolah. Jurnal Panrita Abdi, 4(2), 146 - 154. 